\title{
Hubungan Pengetahuan, Sikap, dan Dukungan Sosial dengan Pemberian Asi Eksklusif: Sebuah Kajian Literatur
}

\section{Relationship of Knowledge, Attitudes, and Social Support with Exclusive Breastfeeding: A Literature Review}

\author{
Kusuma Estu Werdani ${ }^{1}$, Fauzi Abdi Prakosa ${ }^{2}$, Tiyas Mariza Khoirunnisa ${ }^{3}$ \\ Program Studi Kesehatan Masyarakat, Universitas Muhammadiyah Surakarta ${ }^{123}$ \\ Email: kusuma.werdani@ums.ac.id
}

\begin{abstract}
This research is in the form of a literature review. This study aimed to compare the literature on the relationship between knowledge, attitudes, and social support with exclusive breastfeeding. The keywords used were knowledge, attitudes, social support, and exclusive breastfeeding. The literature source was obtained from the Google Scholar database with a limit of the last five years. The literature was excavated by using crosssectional research. There were 3220 works of literature obtained from the search results using keywords, then selected gradually according to predetermined criteria in order to obtain eight literature that was studied and analyzed in depth. The results of the study obtained information that not all literature displays data on the characteristics of respondents and only a part of it displays data on research methods completely. The entire literature uses respondents who number under 100 people. The results of the bivariate analysis of the whole article showed that the majority had significant values for the analysis of the relationship between knowledge, attitudes, and social support with exclusive breastfeeding. Social support in this study consists of support from husbands, families, and health workers. Subsequent research is suggested to increase the number of respondents involved and detail the support variables studied.
\end{abstract}

Keywords : Knowledge, Attitudes, Social Support

\section{ABSTRAK}

Penelitian ini berbentuk kajian literatur. Penelitian ini bertujuan untuk membandingkan literaturliteratur yang berisi tentang hubungan pengetahuan, sikap, dan dukungan sosial dengan pemberian ASI eksklusif. Kata kunci yang digunakan adalah, pengetahuan, sikap, dukungan sosial, dan ASI eksklusif. Sumber literatur diperoleh dari data base di Google Scholar dengan batasan lima tahun terakhir. Literatur yang digali dengan jenis penelitian cross-sectional. Ada sebanyak 3220 literatur yang diperoleh dari hasil pencarian menggunakan kata kunci, kemudian diseleksi secara bertahap sesuai dengan kriteria yang telah ditentukan sehingga diperoleh delapan literatur yang dikaji dan dianalisis secara mendalam. Hasil pengkajian diperoleh informasi bahwa tidak semua literatur menampilkan data karakteristik responden dan hanya sebagian saja yang menampilkan data metode penelitian secara lengkap. Keseluruhan literatur menggunakan responden yang berjumlah di bawah 100 orang. Hasil analisis bivariat keseluruhan artikel menunjukkan bahwa mayoritas memiliki nilai yang signifikan untuk analisis hubungan pengetahuan, sikap, dan dukungan sosial dengan pemberian ASI eksklusif. Dukungan sosial dalam pengkajian ini terdiri atas dukungan suami, keluarga, dan tenaga kesehatan. Penelitian berikutnya disarankan untuk memperbanyak responden yang dilibatkan dan memperinci variabel dukungan yang diteliti.

Kata Kunci : Pengetahuan, Sikap, Dukungan Sosial

\section{PENDAHULUAN}

Menyusui merupakan salah satu cara yang paling efektif untuk meningkatkan nutrisi pada bayi. Di beberapa negara berkembang, menyusui bayi setelah dilahirkan dan berlanjut pada pemberian makanan pendamping air susu ibu (MP-ASI) yang tepat dapat mengurangi kejadian stunting hingga 20\% pada bayi usia 0-12 bulan (UNICEF, 2012). Akan tetapi, pentingnya pemberian air susu ibu (ASI) ini belum diiringi dengan cakupan pemberian ASI 
eksklusif yang tinggi. Menurut data Riset Kesehatan Dasar tahun 2018, cakupan pemberian ASI eksklusif di Indonesia sebesar 37,3\% yang masih jauh dari target nasional (80\%) dan target global (50\%) (USAID, 2014). Cakupan paling tinggi dimiliki oleh Provinsi Bangka Belitung $(56,7 \%)$ dan paling rendah Provinsi Nusa Tenggara Barat (20,3\%). Provinsi Jawa Tengah menduduki peringkat ke-7 yang memiliki cakupan terendah (Kementerian Kesehatan RI, 2018).

Usia ibu menyusui menjadi faktor yang sangat penting. Ibu yang usia remaja merupakan kelompok spesifik yang memiliki keterbatasan baik kemampuan kognitif maupun psikologis. Ibu remaja cenderung memiliki kecemasan yang lebih tinggi dibandingkan dengan ibu dewasa dalam menyusui (Johnson, 2014). Para ibu remaja cenderung membutuhkan tenaga kesehatan untuk menjelaskan tentang cara menyusui dan pendampingan untuk menyusui, terutama saat mereka sudah kembali bekerja (Pentecost \& Grassley, 2014). Selain itu, ibu remaja yang mendapatkan dukungan dari suaminya cenderung memiliki durasi menyusui lebih lama, padahal sebelumnya memiliki niat menyusui dengan durasi lebih pendek (Rempel et al., 2017). Akan tetapi, penelitian lain menunjukkan hasil yang berbeda bahwa intervensi oleh nenek dan suami justru memperpendek durasi menyusui (Emmott \& Mace, 2015).

Pendampingan khusus kepada ibu remaja sangat dibutuhkan, apalagi dengan menyesuaikan keadaan dan budaya di sekitarnya. Hal ini akan mempermudah ibu remaja untuk beradaptasi sebagai orang tua baru (Lewin et al., 2015). Keikutsertaan ibu bayi usia 2 tahun ke dalam sebuah komunitas yang mendukung ternyata dapat memberikan keuntungan terhadap status gizi bayinya (Undlien et al., 2016). Selain itu, keterlibatan suami dalam kelompok pendukung ASI menunjukkan peningkatan yang signifikan terhadap kepercayaan diri ibu untuk menyusui, durasi menyusui yang lebih lama, dan kesadaran untuk melibatkan pasangan selama proses menyusui (Abbass-Dick et al., 2015).

Penelitian ini bertujuan untuk melakukan pengkajian beberapa literatur yang berkaitan dengan pengetahuan, sikap, dan dukungan social dengan pemberian ASI eksklusif pada ibu di beberapa wilayah. Oleh karena itu, peneliti melakukan analisis terhadap beberapa penelitian untuk diperbandingkan dalam proses kajian literatur.

\section{METODE}

Penelitian ini menggunakan kajian literatur tentang pengetahuan, sikap, dan motivasi dengan pemberian ASI eksklusif. Kajian literatur dilakukan dengan cara mereview beberapa literatur dari database yang digunakan.

Penelusuran literatur yang digunakan menggunakan database melalui Google Scholar yang berbahasa Indonesia. Batasan tahun literatur yang digunakan adalah lima tahun terakhir (2015-2020). Kata kunci yang digunakan dalam kajian literatur ini adalah pengetahuan, sikap, motivasi, dan ASI eksklusif. Adapun beberapa kriteria inklusi yang ditetapkan dalam penelitian ini antara lain:

1. Variabel bebas penelitian adalah pengetahuan, sikap, dan dukungan

2. Variabel terikat penelitian adalah ASI eksklusif

3. Tahun literatur diterbitkan minimalpada tahun 2015

4. Responden penelitian adalah ibu muda

5. Desain penelitian adalah cross-sectional 
Seleksi literatur dilakukan dalam beberapa tahapan sebagaimana dapat dilihat pada diagram alur berikut:

Sebanyak 3220 literatur teridentifikasi dengan menggunakan kata kunci (pengetahuan, sikap, motivasi, ASI eksklusif) melalui database Google

Scholar dengan batasan bawah tahun artikel 2015.

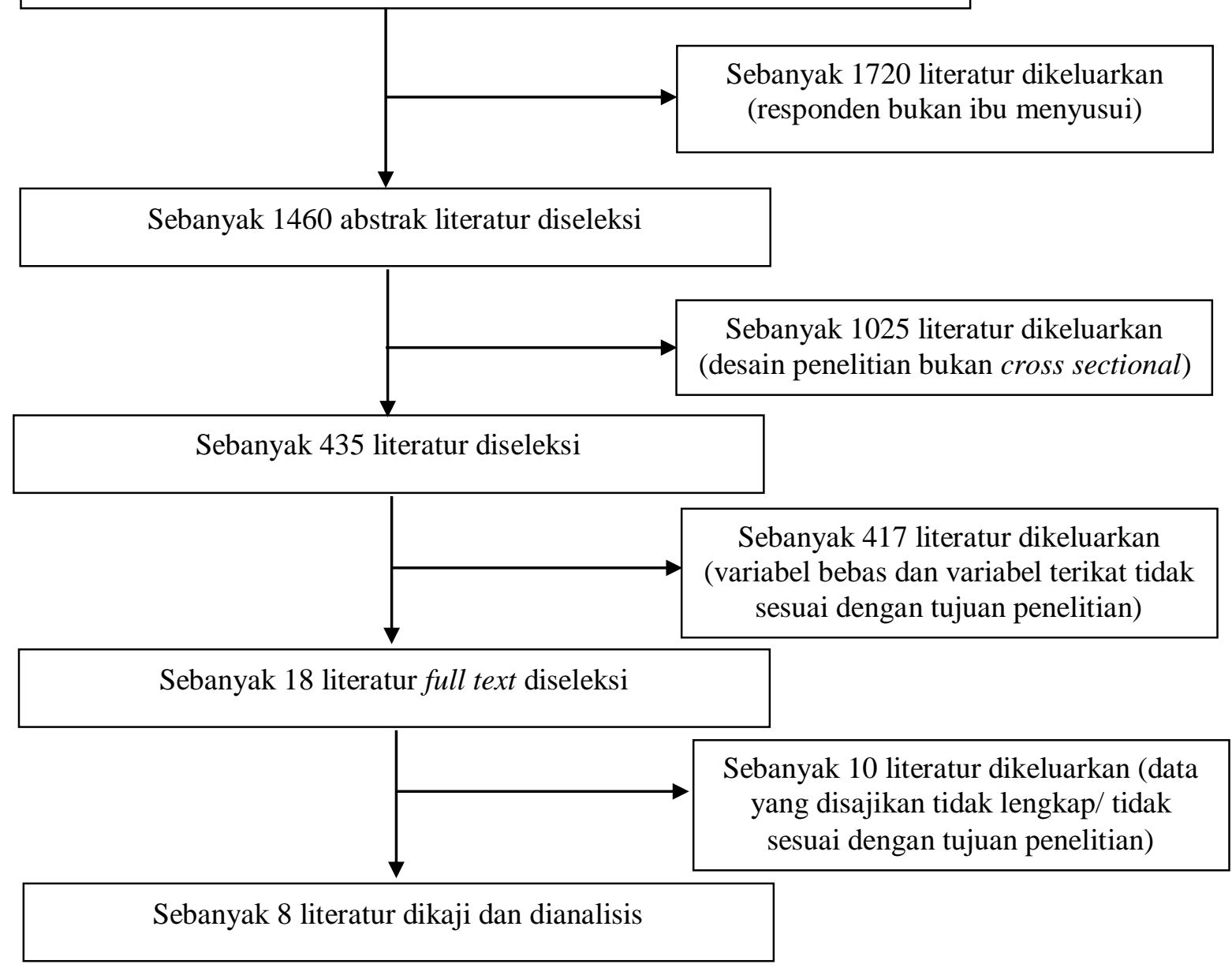

Gambar 1. Alur Seleksi Artikel 


\section{HASIL DAN PEMBAHASAN}

\section{Hasil Kajian Literatur tentang Karakteristik Responden}

Ada delapan literatur yang masuk dalam proses analisis, akan tetapi hanya ada dua literatur yang menampilkan data tentang karakteristik responden. Data tentang perbandingan karakteristik responden dari empat artikel tersebut dapat dilihat pada Tabel 1.

Tabel 1. Hasil Kajian Literatur Karakteristik Responden

\begin{tabular}{clccc}
\hline Karakteristik & \multicolumn{2}{c}{ Fau, dkk (2019) } & Azhari AS \& Pristya TYR \\
& \multicolumn{1}{c}{ Kategori } & n (\%) & Kategori & n (\%) \\
\cline { 2 - 5 } & 15 & $8(8,3)$ & $20-35$ th & $42(84)$ \\
& 16 & $18(18,8)$ & $<20$ th dan $>35$ th & $8(16)$ \\
& 17 & $18(18,8)$ & & \\
& 18 & $27(28,1)$ & & \\
& 19 & $19(19,8)$ & & \\
& 20 & $6(6,8)$ & & \\
& Tidak tamat SD & $19(19,8)$ & Rendah \\
& SD & $38(39,6)$ & Tinggi & $22(44)$ \\
& SMP & $33(34,4)$ & & $28(56)$ \\
& SMA & $6(6,3)$ & & \\
\hline & Tidak bekerja & $43(44,8)$ & Tidak bekerja & \\
& Petani & $47(48,9)$ & Bekerja & \\
\hline
\end{tabular}

Pembagian kategori usia antara dua artikel memiliki perbedaan. Fau, dkk (2019) melibatkan ibu usia remaja sehingga pembagian kategori usia $<20$ tahun. Sedangkan Azhari AS \& Pristya TYR (2019) membagi kategori usia berdasarkan tingkat risiko kehamilan, yaitu 20-35 tahun dan $<20$ tahun dan/ $>35$ tahun (Tabel 1).

Berdasarkan kategori pendidikan, hanya tiga artikel yang menampilkan data tersebut. Artikel Fau, dkk (2019) menampilkan data pendidikan lebih rinci (setiap level), sedangkan penelitian Azhari AS \& Pristya TYR (2019) membagi pendidikan menjadi dua kategori (tinggi dan rendah). Pada artikel Fau, dkk (2019) menunjukkan bahwa mayoritas responden berpendidikan rendah. Hal ini berkebalikan dengan data pendidikan pada artikel Azhari AS \& Pristya TYR (2019) (Tabel 1).

Hanya Fau, dkk (2019) yang menampilkan jenis pekerjaan secara rinci. Sedangkan penelitian Azhari AS \& Pristya TYR (2019) membagi pekerjaan menjadi kategori bekerja dan tidak bekerja. Persentase responden yang bekerja pada kedua artikel lebih tinggi daripada yang tidak bekerja (Tabel 1).

\section{Hasil Kajian Literatur tentang Metode Penelitian}

Analisis perbandingan metode penelitian menampilkan beberapa informasi yang meliputi jenis penelitian, populasi dan sampel, teknik sampling, dan lokasi penelitian. 
Tabel 2. Hasil Kajian Literatur Metode Penelitian

\begin{tabular}{|c|c|c|c|c|c|c|}
\hline $\begin{array}{l}\text { Metode } \\
\text { penelitian }\end{array}$ & $\begin{array}{l}\text { Fau, dkk } \\
(2019)\end{array}$ & $\begin{array}{l}\text { Caitom CD, } \\
\text { dkk (2019) }\end{array}$ & $\begin{array}{l}\text { Limbat RDC, } \\
\text { dkk (2020) }\end{array}$ & $\begin{array}{c}\text { Azhari AS \& } \\
\text { Pristya TYR } \\
\text { (2019) }\end{array}$ & $\begin{array}{c}\text { Juliani S \& } \\
\text { Arma N } \\
(\text { 2018) }\end{array}$ & $\begin{array}{c}\text { Trismiya } \\
\text { na E \& } \\
\text { Winata } \\
\text { NS (2019) }\end{array}$ \\
\hline $\begin{array}{l}\text { Jenis } \\
\text { penelitian }\end{array}$ & $\begin{array}{l}\text { Survei } \\
\text { analitik, cross } \\
\text { section-nal }\end{array}$ & $\begin{array}{l}\text { Survei analitik, } \\
\text { cross sectional }\end{array}$ & $\begin{array}{l}\text { Survei } \\
\text { analitik, cross } \\
\text { sectional }\end{array}$ & $\begin{array}{l}\text { Survei } \\
\text { analitik, cross } \\
\text { sectional }\end{array}$ & $\begin{array}{l}\text { Survei } \\
\text { analitik, cross } \\
\text { sectional }\end{array}$ & $\begin{array}{l}\text { Survei } \\
\text { analitik, } \\
\text { cross } \\
\text { sectional }\end{array}$ \\
\hline $\begin{array}{l}\text { Populasi } \\
\text { dan sampel }\end{array}$ & $\begin{array}{lr}\text { Ibu } & \text { usia } \\
\text { remaja } & \text { yang } \\
\text { memiliki } & \text { bayi } \\
\text { usia } & 6-12 \\
\text { bulan } & \end{array}$ & $\begin{array}{l}\text { Ibu menyusui dg } \\
\text { bayi } 6-12 \text { bulan, } \\
67 \text { orang }\end{array}$ & $\begin{array}{lr}\text { Ibu menyusui } \\
\text { dg bayi } & 6-12 \\
\text { bulan, } & 77 \\
\text { orang }\end{array}$ & $\begin{array}{lr}\text { Ibu } & \text { dengan } \\
\text { bayi } & 6-24 \\
\text { bulan, } & \text { pasien } \\
\text { rawat } & \text { jalan } \\
\text { klinik } & \end{array}$ & $\begin{array}{lr}\text { Ibu bayi } & 6-12 \\
\text { bulan, } & 120 \\
\text { orang } & \end{array}$ & $\begin{array}{l}\text { Tidak ada } \\
\text { informasi }\end{array}$ \\
\hline $\begin{array}{l}\text { Teknik } \\
\text { sampling }\end{array}$ & $\begin{array}{l}\text { Total } \\
\text { sampling }\end{array}$ & $\begin{array}{l}\text { Tidak } \\
\text { informasi }\end{array}$ & $\begin{array}{l}\text { Purposive } \\
\text { sampling }\end{array}$ & $\begin{array}{l}\text { Purposive } \\
\text { sampling }\end{array}$ & $\begin{array}{l}\text { Accidental } \\
\text { sampling }\end{array}$ & $\begin{array}{l}\text { Proportion } \\
\text { al random } \\
\text { sampling }\end{array}$ \\
\hline Lokasi & $\begin{array}{l}\text { Puskes-mas } \\
\text { Sario, } \\
\text { Manado, Mei- } \\
\text { Sept } 2019\end{array}$ & $\begin{array}{l}\text { Desa Cikeruh, } \\
\text { Jatinangor, } \\
\text { Sume-dang, } \\
\text { Agustus } 2015\end{array}$ & $\begin{array}{l}\text { RSIA Budi } \\
\text { Kemulia-an } \\
\text { Jakarta }\end{array}$ & $\begin{array}{l}\text { Puskesmas } \\
\text { Darussalam } \\
\text { Kec. Medan } \\
\text { Petisah }\end{array}$ & $\begin{array}{l}\text { Puskesmas } \\
\text { Kedondong } \\
\text { Kab. } \\
\text { Pesawaran } \\
\text { Lampung }\end{array}$ & $\begin{array}{l}\text { Puskesma } \\
\text { s Sario, } \\
\text { Manado, } \\
\text { Mei-Sept } \\
2019 \\
\end{array}$ \\
\hline
\end{tabular}

Ada enam artikel yang menampilkan data metode penelitian lengkap. Keseluruhan artikel menggunakan jenis penelitian survei analitik dengan pendekatan cross-sectional. Hanya penelitian Fau, dkk (2019) yang melibatkan ibu remaja yang memiliki bayi usia 6-12 bulan. Ibu yang memiliki bayi 6-24 bulan hanya dilibatkan dalam penelitian Juliani S \& Arma N (2018) (Tabel 2).

Ada enam artikel yang menampilkan data teknik sampling yang bervariasi. Hanya penelitian Juliani S \& Arma N (2018) yang menggunakan accidental sampling dan hanya penelitian Trismiyana \& Winata (2020) yang menggunakan proportional random sampling. Dua penelitian menggunakan purposive sampling dan hanya penelitian Fau, dkk (2019) yang menggunakan total sampling dan (Tabel 2).

Lima penelitian dilakukan di wilayah kerja puskesmas. Hanya penelitian Caitom et al. (2019) yang melakukan penelitian di wilayah desa dan penelitian Limbat, et al (2020) yang melakukan penelitian di rumah sakit ibu dan anak (Tabel 2). Sebaran tempat penelitian di tiga pulau, yaitu Jawa, Sumatera, dan Sulawesi.

\section{Hasil Kajian Literatur tentang Analisis Bivariat}

Ada delapan literatur yang menampilkan data hubungan variabel bebas (pengetahuan, sikap, dukungan sosial) dengan variabel terikat (ASI eksklusif). Ada enam (75\%) literatur yang menunjukkan hasil signifikan tentang hubungan pengetahuan dengan ASI Eksklusif. Hampir keseluruhan literatur (87,5\%) memiliki kecenderungan sama yaitu responden yang tidak memberikan ASI eksklusif memiliki pengetahuan yang kurang (Tabel $3)$.

Hanya ada tiga literatur yang menampilkan hasil analisis hubungan sikap dengan ASI Eksklusif dan keseluruhan hasilnya menunjukkan adanya hubungan yang signifikan. Pada kelompok responden yang tidak memberikan ASI eksklusif, persentase yang memiliki sikap negatif lebih besar daripada yang memiliki sikap positif (Tabel 3).

Untuk faktor dukungan sosial, beberapa artikel menunjukkan adanya macam dukungan sosial yang meliputi dukungan suami, dukungan keluarga, dan dukungan tenaga kesehatan. Hanya ada satu literatur yang menganalisis dukungan suami dengan ASI Eksklusif dan memiliki hasil yang signifikan. Ada tiga literatur yang menganalisis hubungan dukungan keluarga dengan pemberian ASI Eksklusif dan dua diantaranya memiliki hasil 
yang signifikan. Hanya ada dua literatur yang menganalisis hubungan dukungan tenaga kesehatan dengan pemberian ASI eksklusif dengan hasil yang signifikan. Hampir keseluruhan hasil analisis dukungan memiliki kecenderungan bahwa responden yang tidak ASI eksklusif memiliki persentase dukungan yang kurang (tidak mendukung) lebih besar dibandingkan yang mendukung, baik dari suami, keluarga, maupun tenaga kesehatan (Tabel $3)$.

Tabel 3. Hasil Kajian Literatur Analisis Hubungan Variabel Bebas (Pengetahuan, Sikap, Dukungan Sosial) Dengan Variabel Terikat (ASI Eksklusif)

\begin{tabular}{|c|c|c|c|c|}
\hline \multirow{2}{*}{$\begin{array}{l}\text { Penulis } \\
\text { (Tahun) }\end{array}$} & \multirow[t]{2}{*}{ Variabel Bebas } & \multicolumn{2}{|c|}{ Asi Eksklusif } & \multirow[t]{2}{*}{ P-Value } \\
\hline & & Tidak Asi Eksklusif & Asi Eksklusif & \\
\hline \multirow{18}{*}{$\begin{array}{l}\text { Fau, Dkk } \\
\text { (2019) }\end{array}$} & Pengetahuan & & & \\
\hline & Kurang & $56(87,5)$ & $8(12,5)$ & 0,004 \\
\hline & Baik & $20(62,5)$ & $12(37,5)$ & \\
\hline & Sikap & & & \\
\hline & Negatif & $52(96,3)$ & $2(3,7)$ & 0,001 \\
\hline & Positif & $24(57,1)$ & $18(42,9)$ & \\
\hline & Keyakinan & & & \\
\hline & Kurang & $64(94,1)$ & $4(5,9)$ & 0,001 \\
\hline & Baik & $12(42,9)$ & $16(57,1)$ & \\
\hline & Dukungan Tenaga Kes & & & \\
\hline & Tidak Mendukung & $61(95,3)$ & $3(4,7)$ & 0,001 \\
\hline & Mendukung & $15(46,9)$ & $17(53,1)$ & \\
\hline & Dukungan Suami & & & \\
\hline & Tidak Mendukung & 7392,4 & $6(7,6)$ & 0,001 \\
\hline & Mendukung & $3(17,6)$ & $14(82,4)$ & \\
\hline & Pengaruh Media Sosia & & & \\
\hline & Kurang & $70(88,6)$ & $9(11,4)$ & 0,001 \\
\hline & Baik & $6(35,3)$ & $11(64,7)$ & \\
\hline \multirow{6}{*}{$\begin{array}{l}\text { Caitom Cd, } \\
\text { Dkk (2019) }\end{array}$} & Pengetahuan & & & \\
\hline & Kurang & $7(24,14)$ & $22(75,86)$ & 0,065 \\
\hline & Baik & $3(7,9)$ & $35(92,1)$ & \\
\hline & Sikap & & & \\
\hline & Negatif & $7(26,92)$ & $19(73,08)$ & 0,028 \\
\hline & Positif & $3(7,32)$ & $38(92,68)$ & \\
\hline Limbat & Pengetahuan & & & \\
\hline \multirow{8}{*}{$\begin{array}{l}\text { Rdc, Dkk } \\
(2020)\end{array}$} & Kurang & $18(60)$ & $12(40)$ & 0,028 \\
\hline & Baik & $15(31,91)$ & $32(68,09)$ & \\
\hline & Peran Nakes & & & \\
\hline & Kurang & $15(62,5)$ & $9(37,5)$ & 0,036 \\
\hline & Baik & $18(33,96)$ & $35(66,04)$ & \\
\hline & Peran Suami & & & \\
\hline & Kurang & $13(68,42)$ & $6(31,58)$ & 0,02 \\
\hline & Baik & $20(34,48)$ & $38(65,52)$ & \\
\hline Azhari As & Pengetahuan & & & \\
\hline \& Pristya & Kurang & $3(60)$ & $2(40)$ & 0,273 \\
\hline \multirow{5}{*}{ Tyr (2019) } & Cukup & $3(21,43)$ & $11(78,57)$ & \\
\hline & Baik & $9(29,03)$ & $22(70,97)$ & \\
\hline & Dukungan Suami Dan & Irga & & \\
\hline & Kurang & $7(20)$ & $28(80)$ & 0,040 \\
\hline & Cukup & $8(53,33)$ & $7(46,67)$ & \\
\hline \multirow{5}{*}{$\begin{array}{l}\text { Solama W } \\
(2018)\end{array}$} & Umur & & & \\
\hline & Risiko Tinggi & $7(77,78)$ & $2(22,22)$ & 0,015 \\
\hline & Risiko Rendah & $6(26,09)$ & $17(73,91)$ & \\
\hline & Pengetahuan & & & \\
\hline & Kurang & $10(83,33)$ & $2(16,67)$ & $<0,0001$ \\
\hline
\end{tabular}


Tabel 3. Hasil Kajian Literatur Analisis Hubungan Variabel Bebas (Pengetahuan, Sikap, Dukungan Sosial) Dengan Variabel Terikat (ASI Eksklusif) (Lanjutan)

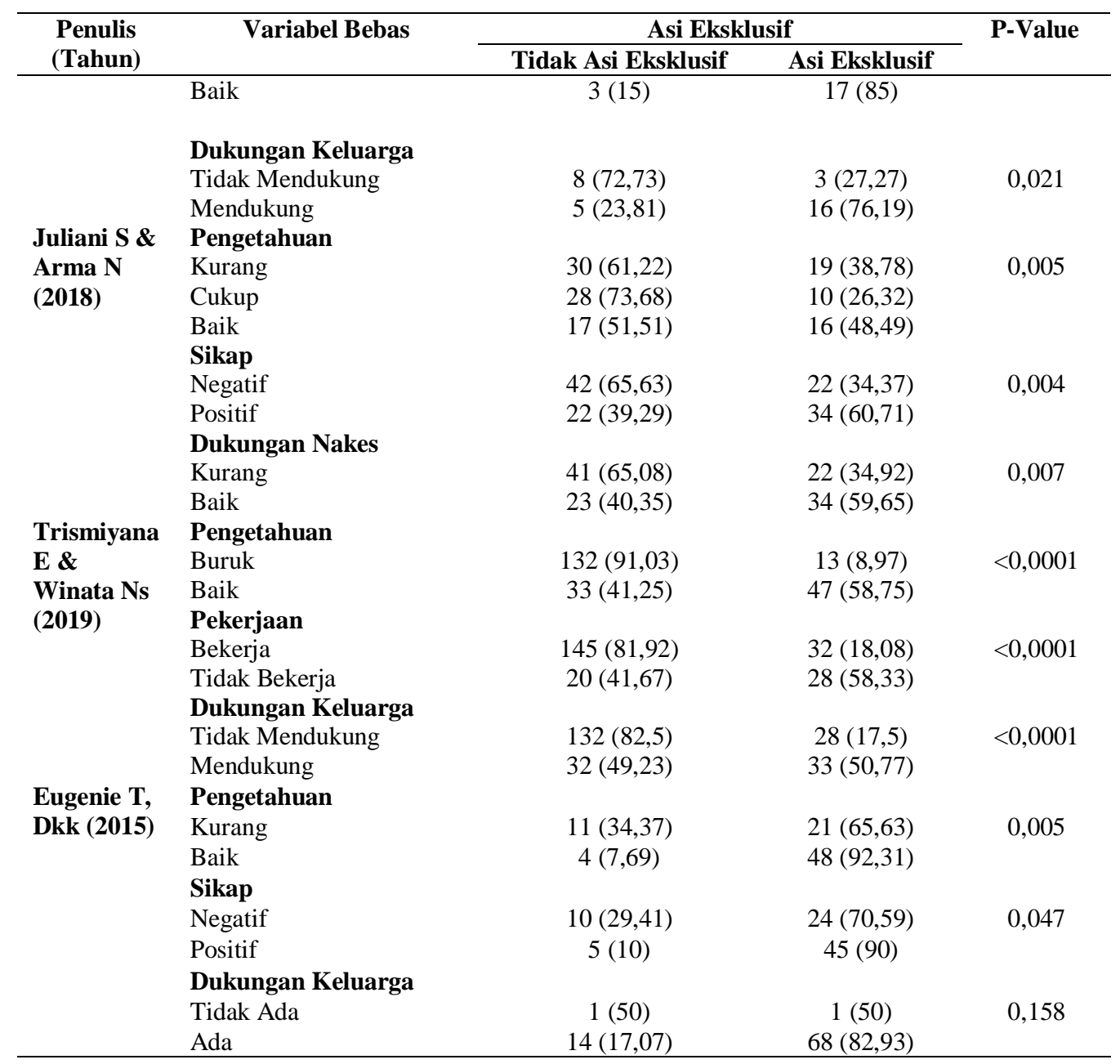

\section{Hubungan Pengetahuan dengan ASI Eksklusif}

Pengetahuan merupakan salah satu faktor penentu dalam praktik pemberian ASI eksklusif. Ada enam (75\%) literatur yang menunjukkan hasil signifikan tentang hubungan pengetahuan dengan ASI Eksklusif. Hampir keseluruhan literatur (87,5\%) memiliki kecenderungan sama yaitu responden yang tidak memberikan ASI eksklusif memiliki pengetahuan yang kurang (Tabel 3).

Pengetahuan tentang ASI eksklusif pada responden bisa berasal dari mana saja, baik internet, konsultan ASI, keluarga, maupun teman. Sebagaimana menurut Utari, et al (2013), sebagian besar ibu post-partum di Kecamatan Dramaga, Kabupaten Bogor, memiliki pengetahuan baik tentang ASI yang bersumber dari tenaga kesehatan/bidan. Menurutnya, apapun pendidikan responden sebenarnya tidak mempengaruhi tinggi atau rendahnya pengetahuan tentang ASI. Akan tetapi, Amin et al. (2014) mengansumsikan bahwa orang yang berpendidikan tinggi akan mudah menerima informasi dan diberikan motivasi untuk melakukan hal yang lebih baik, seperti menyusui. Hal ini sejalan dengan artikel pada kajian literatur ini, yaitu penelitian Fau et al., (2019) memiliki mayoritas responden berpendidikan rendah dengan persentase kelompok yang tidak ASI eksklusif cukup tinggi. Hal ini berkebalikan dengan penelitian Azhari AS \& Pristya TYR (2019) yang menunjukkan sebagian besar responden berpendidikan tinggi dengan persentase kelompok yang ASI 
eksklusif-lah yang lebih tinggi. Hal ini dapat disimpulkan bahwa pendidikan bisa menjadi faktor tinggi rendahnya akses terhadap peningkatan pengetahuan tentang ASI eksklusif.

Persentase responden yang bekerja pada kedua artikel (Fau, et al, 2019 dan Azhari AS \& Pristya TYR, 2019) lebih tinggi daripada yang tidak bekerja. Kondisi ibu yang tidak bekerja dimungkinkan akan memiliki banyak waktu untuk menyusui. Sebagaimana penelitian Oktoviyanda et al (2013) yang menyimpulkan bahwa ibu yang tidak bekerja memiliki praktik penyapihan yang baik. Hal ini dikarenakan ibu bekerja memiliki waktu yang terbatas sehingga berhenti menyusui bayinya lebih cepat.

\section{Hubungan Sikap dengan ASI Eksklusif}

Hanya ada tiga literatur yang menampilkan hasil analisis hubungan sikap dengan ASI Eksklusif dan keseluruhan hasilnya menunjukkan adanya hubungan yang signifikan. Pada kelompok responden yang tidak memberikan ASI eksklusif, persentase yang memiliki sikap negatif lebih besar daripada yang memiliki sikap positif. Hal ini sejalan dengan penelitian Cox, et al (2015) yang menyatakan bahwa ibu yang memiliki sikap lebih positif akan menyusui bayinya lebih lama.

Pembentukan sebuah sikap positif terhadap ASI eksklusif bisa berdasarkan usia ibu. Faktor usia ibu menentukan kualitas gizi yang akan diberikan kepada bayinya, salah satunya memalui proses menyusui. Sebagaimana hasil penelitian Wemakor, et al (2018) yang menunjukkan bahwa ibu yang masih berusia remaja memiliki bayi yang cenderung mengalami malnutrisi. Hal ini sejalan dengan artikel yang dikaji dalam penelitian ini. Penelitian Fau, et al, 2019 yang melibatkan ibu usia remaja ( $<20$ tahun) dalam penelitiannya memiliki persentase kelompok yang ASI eksklusif lebih rendah daripada yang tidak ASI eksklusif. Berkebalikan dengan penelitian Azhari AS \& Pristya TYR (2019) yang mayoritas responden berusia lebih dewasa (20-35 tahun) sehingga persentase kelompok yang ASI eksklusif lebih tinggi daripada yang tidak ASI eksklusif.

\section{Hubungan Dukungan Sosial dengan ASI Eksklusif}

Hampir keseluruhan hasil analisis dukungan pada kajian literatur ini memiliki kecenderungan bahwa responden yang tidak ASI eksklusif memiliki persentase dukungan yang kurang (tidak mendukung) lebih besar dibandingkan yang mendukung, baik dari suami, keluarga, maupun tenaga kesehatan. Menurut Rahmayanti, et al (2018), dukungan keluarga merupakan faktor penting untuk meningkatkan kepercayaan diri ibu selama menyusui. Hal ini dikarenakan adanya perbedaan informasi yang diperoleh ibu tentang menyusui sehingga memerlukan dukungan dari keluarga untuk meyakinkan ibu dalam memberikan ASI eksklusif.

Sikap yang positif terhadap ASI eksklusif dapat dibentuk oleh lingkungan di sekitar ibu, baik suami, keluarga, maupun tenaga kesehatan. Pada artikel Trismiyana \& Winata (2020), dukungan tenaga kesehatan sangat diperlukan melalui pemberian penyuluhan yang lebih inovatif kepada ibu menyusui. Saran-saran yang diberikan oleh tenaga kesehatan cenderung akan meningkatkan kepercayaan terhadap informasi yang diterimanya (Lee et al., 2013). Ditambah dengan rekomendasi dari Amin, et al (2014) agar suami memberikan dukungan yang tinggi sehingga keberhasilan ibu menyusui pada dua bulan pertama juga tinggi. Koralage, et al (2018) juga menemukan bahwa pada kelompok ibu yang diberikan intervensi berupa keterlibatan suami dalam proses menyusui menunjukkan memiliki sikap yang lebih positif terhadap ASI eksklusif dibandingkan kelompok yang tidak diberikan intervensi. 


\section{KESIMPULAN}

Hasil pengkajian diperoleh informasi bahwa tidak semua literatur menampilkan data karakteristik responden dan hanya sebagian saja yang menampilkan data metode penelitian secara lengkap. Keseluruhan literatur menggunakan responden yang berjumlah di bawah 100 orang. Hasil analisis bivariat keseluruhan artikel menunjukkan bahwa mayoritas memiliki nilai yang signifikan untuk analisis hubungan pengetahuan, sikap, dan dukungan sosial dengan pemberian ASI eksklusif. Dukungan sosial dalam pengkajian ini terdiri atas dukungan suami, keluarga, dan tenaga kesehatan.

\section{SARAN}

Penelitian berikutnya disarankan untuk melakukan pengkajian literatur yang lebih luas dalam penggunaan database dan penentuan metode penelitiannya.

\section{DAFTAR PUSTAKA}

Abbass-Dick, J., Stern, S. B., Nelson, L. E., Watson, W., \& Dennis, C.-L. (2015). Coparenting Breastfeeding Support and Exclusive Breastfeeding: A Randomized Controlled Trial. $\begin{array}{lll}\text { Pediatrics, } & 102 .\end{array}$ https://search.proquest.com/docview/1645772790?accountid=10382\%0Ahttp://link.library.cu rtin.edu.au/openurl??url_ver=Z39.88-

2004\&rft_val_fmt=info:ofi/fmt:kev:mtx:journal\&genre=article\&sid=ProQ:ProQ\%3Acentral \&atitle=Coparenting + Breastfeeding + Support+and+Exc

Amin, W., I, I. W. A., \& W, E. S. (2014). Pengaruh Faktor Sosial Ibu terhadap Keberhasilan Menyusui pada Dua Bulan Pertama. Jurnal Kedokteran Brawijaya, 28(2), 146-151.

Caitom, C. D., Rumayar, A. A., Tucunan, A. A. T., Kesehatan, F., Universitas, M., Ratulangi, S., \& Sario, P. (2019). Hubungan Pengetahuan dan Sikap dengan Pemberian ASI Eksklusif di Wilayah Kerja Puskesmas Sario Kota Manado. Jurnal KESMAS, 8(7), 108-114.

Condon, L., Rhodes, C., Warren, S., Withall, J., \& Tapp, a. (2012). "But is it a normal thing?" Teenage mothers' experiences of breastfeeding promotion and support. Health Education Journal, 72(2), 156-162. https://doi.org/10.1177/0017896912437295

Cox, K. N., Giglia, R. C., \& Binns, C. W. (2015). The influence of infant feeding attitudes on breastfeeding duration: evidence from a cohort study in rural Western Australia. International Breastfeeding Journal, 10(1), 25. https://doi.org/10.1186/s13006-015-0048-3

Emmott, E. H., \& Mace, R. (2015). Practical support from fathers and grandmothers is associated with lower levels of breastfeeding in the UK millennium cohort study. PLOS ONE, 10(7), 112. https://doi.org/10.1371/journal.pone.0133547

Fau, S. Y., Nasution, Z., \& Hadi, A. J. (2019). Faktor Presdiposisi Ibu Usia Remaja Terhadap Pemberian ASI Eksklusif pada Bayi di Kecamatan Luahagundre Maniamolo Kabupaten Nias Selatan. Media Publikasi Promosi Kesehatan Indonesia, 2(2), 165. https://doi.org/10.1119/1.2218359

Florescu, L., Temneanu, O. R., \& Mindru, D. E. (2016). Social and Medical Implications of Teenage Motherhood. Revista de Cercetare Si Interventie Sociala, 52, 80-91. http://www.rcis.ro/images/documente/rcis52_05.pdf 
Johnson, S. M. (2014). Breastfeeding Initiation Among Teenage Mothers. Journal of Student Nursing Research, 3(2).

Kanhadilok, S., \& McGrath, J. M. (2015). An Integrative Review of Factors Influencing Breastfeeding in Adolescent Mothers. The Journal of Perinatal Education, 24(2), 119-127. https://doi.org/10.1891/1946-6560.24.2.119

Kementerian Kesehatan RI. (2018). Hasil Utama Riset Kesehatan Dasar 2018.

Kiptanui CB, Kindiki JN, \& Lelan JK. (2015). Impact of teenage motherhood on the academic performance in public primary schools in Bungoma County, Kenya. International Journal of Educational Administration and Policy Studies, 7(2), 61-71. https://doi.org/10.5897/IJEAPS2014.0383

Kompasiana. (2017). BKKBN: Usia Pernikahan Ideal Berkisar 21-25 Tahun. https://www.republika.co.id/berita/nasional/umum/17/03/06/omduca359-bkkbn-usiapernikahan-ideal-berkisar-2125-tahun

Koralage, P., Mahesh, B., Gunathunga, M. W., Arnold, S. M., Jayasinghe, C., Pathirana, S., Makarim, M. F., \& Manawadu, P. M. (2018). Effectiveness of targeting fathers for breastfeeding promotion : systematic review and meta-analysis. BMC Public Health, 18(1140), $1-15$.

Lee, H. M. H., Durham, J., Booth, J., \& Sychareun, S. (2013). A qualitative study on the breastfeeding experiences of first-time mothers in Vientiane, Lao PDR. In BMC Pregnancy and Childbirth (Vol. 13). https://doi.org/10.1186/1471-2393-13-223

Lewin, A., Hodgkinson, S., Waters, D. M., Prempeh, H. A., Beers, L. S., \& Feinberg, M. E. (2015). Strengthening Positive Coparenting in Teen Parents: A Cultural Adaptation of an EvidenceBased Intervention. The Journal of Primary Prevention, 36(3), 139-154. https://doi.org/10.1007/s10935-015-0388-1

Limbat, R. D. C., Engkeng, S., \& Punuh, M. I. (2020). PADA BAYI USIA 6-12 BULAN DI WILAYAH KERJA PUSKESMAS PINELENG Air Susu Ibu ( ASI ) Eksklusif adalah memberikan ASI kepada bayi dengan tanpa makanan tambahan pada bayi uisa 0-6 sangat bermanfaat dalam menyusui . Peran suami diperlukan dalam mendukung ibu s. Jurnal KESMAS, 9(1), 9-15.

London, W. (2014). enterprise output Supporting teenage mothers to initiate breast feeding and developing a support intervention to increase breast feeding rates in a vulnerable group - the importance of place Thesis.

Mallviya, R., \& Solanki, A. (2015). Teen Pregnancy: Medical Risks and Realities. 3(11), 1623-1628.

Nurafifah, D. (2015). PERAN SUAMI DALAM PEMBERIAN ASI DI DESA LOPANG KECAMATAN KEMBANGBAHU KABUPATEN LAMONGAN Dian Nurafifah. Surya, 07(02), 35-38.

Oktoviyanda, V. D., Ropi, H., \& Mardhiyah, A. (2013). Hubungan Tingkat Pendidikan , Pekerjaan , dan Paritas Ibu dengan Usia Penyapihan pada Balita. Artikel Ilmiah, 1(3), 152-157.

Pentecost, R., \& Grassley, J. S. (2014). Adolescents' Needs for Nurses' Support When Initiating Breastfeeding. Journal of Human Lactation, 30(2), 224-228. 
https://doi.org/10.1177/0890334413510358

Rahmayanti, R., Setyowati, S., \& Afiyanti, Y. (2018). Pengalaman Ibu Remaja Primipara Memperoleh Dukungan Keluarga Dalam Memberikan ASI Eksklusif. Jurnal Kesehatan Mecusuar, 1(1), 1-8. http://jurnal.mercubaktijaya.ac.id/index.php/mnm/article/view/7

Rempel, L. A., Rempel, J. K., \& Moore, K. C. J. (2017). Relationships between types of father breastfeeding support and breastfeeding outcomes. Maternal and Child Nutrition, 13(3). https://doi.org/10.1111/men.12337

Rumiati, F., \& Kusumawati, Y. (2017). Hubungan Pengetahuan, Sikap Dan Dukungan Suami Dengan Pemberian Asi Eksklusif Pada Pasangan Menikah Dini Di Wilayah Kerja Puskesmas Selo Boyolali Tahun 2017 [Universitas Muhammadiyah Surakarta]. http://eprints.ums.ac.id/53229/

Trismiyana, E., \& Winata, N. S. (2020). Faktor - faktor yang berhubungan dengan pemberian ASI eksklusif pada bayi usia 7 - 12 bulan. Holistik Jurnal Kesehatan, 13(4), 348-357. https://doi.org/10.33024/hjk.v13i4.1534

Undlien, M., Viervoll, H. A., \& Rostad, B. (2016). Effect of mother support groups on nutritional status in children under two years of age in Laisamis village, Kenya. African Health Sciences, 16(4), 904-909. https://doi.org/10.4314/ahs.v16i4.4

UNICEF. (2012). Nutrition in the First 1, 000 Days. In The State of the World's Children.

USAID. (2014). Multi-Sectoral Nutrition Strategy: 2014-2025. 58. https://www.usaid.gov/nutritionstrategyl

Utari, A. P., Roosita, K., \& Damanik, M. R. M. (2013). Pengetahuan Gizi, Keluhan Kesehatan, Kondisi Psikologis, dan Pola Pemberian ASI Ibu Postpartum. Jurnal Gizi Dan Pangan, 8((3)), 187-192.

Wemakor, A., Garti, H., Azongo, T., Garti, H., \& Atosona, A. (2018). Young maternal age is a risk factor for child undernutrition in Tamale Metr. BMC Researc Note, 11(1), 877. https://doi.org/10.1186/s13104-018-3980-7

Wylie, S. (2009). Meeting the Needs of Teen Parents and their Children : Promising Practices. Health (San Francisco), November, 1-7. 